\title{
The Person-in-the-Rain Drawing Test as an Assessment of Soldiers' Army Life Adjustment and Resilience
}

\author{
Juliet Jue ${ }^{1 *}$, Jung Hee Ha ${ }^{2}$ \\ ${ }^{1}$ Department of Art Therapy, Hanyang Cyber University, Seoul, Republic of Korea \\ ${ }^{2}$ Graduate School of Counseling Psychology, Hanyang University, Seoul, Republic of Korea \\ Email: *juliet@hycu.ac.kr
}

How to cite this paper: Jue, J., \& Ha, J. H. (2019). The Person-in-the-Rain Drawing Test as an Assessment of Soldiers' Army Life Adjustment and Resilience. Psychology, 10, 1418-1434.

https://doi.org/10.4236/psych.2019.1011093

Received: July 8, 2019

Accepted: August 12, 2019

Published: August 15, 2019

Copyright () 2019 by author(s) and Scientific Research Publishing Inc. This work is licensed under the Creative Commons Attribution International License (CC BY 4.0).

http://creativecommons.org/licenses/by/4.0/

\section{c) (i) Open Access}

\begin{abstract}
This quantitative study investigated the applicability of the Person-in-theRain drawing test (PITR) as a psychological evaluation tool to assess individuals' psychological capacity to deal with stress. The subjects of the study were 300 soldiers from three army units. The study's research tools included the PITR, the Army Life Adjustment Scale, and the Resilience Scale. The study's findings are as follows. First, there was a significant difference in both the Resource subtotal and the Coping capacity score when comparing upper and lower groups in terms of army life adjustment. Second, the higher resilience group showed higher scores in the PITR Resource subtotal than the lower resilience group, although no significant difference was found in the PITR Stress score. Third, when comparing the upper and lower groups based on the PITR Coping capacity score, there were significant differences in both army life adjustment and resilience. Based on these results, the PITR can be considered as a useful tool to evaluate soldiers' army life adjustment and resilience. This study contributes significantly to this area of research by exploring the applicability of the PITR through a two-way examination. The study also suggests relevant implications and potential directions for future research.
\end{abstract}

\section{Keywords}

Person-in-the-Rain Drawing Test, Army Life Adjustment, Resilience, Soldiers

\section{Introduction}

Standardized questionnaires are the most commonly used method for identifying individuals' adjustment problems. A variety of self-report questionnaires can 
be used to assess psychometric properties. Despite the economic advantages of this method, it can sometimes produce invalid results due to respondents' faking goodness for social desirability or conscious defensive responses with internal censorship.

Art assessments have been developed to overcome the limitations of self-report questionnaires and to promote individuals' expression of their inner worlds through nonverbal communication channels (Brooke, 2004). Art assessments are a type of projective tests with indirect questions about the content to be examined. In these kinds of assessments, subjects can express their inner worlds less defensively than through questionnaires or oral interviews.

Among the various drawing tests used in art therapy, the Person-in-the-Rain test is a projective test that evaluates individuals' environmental stress and their ability to cope with it. Previous studies have reported that this test can indicate respondents' psychological stress (Chung, 2012; Jeong \& Kim, 2008; Jue \& Kim, 2011; Kang \& Lee, 2014; Krom, 2002; Lee \& Lee, 2014). Meanwhile, a few studies have reported low relevance between PITR and stress (Kim, 2011; Lee, 2006; Russo, 2007; Willis, Joy, \& Kaiser, 2010; Yang \& Won, 2013). Son (2007) asserted that the reason for this low correlation is that the concept of stress is loose and broad. These results might also be explained by the fact that stress is mediated by various psychological factors that change its influence (Bartone, Kelly, \& Matthews, 2013; Hyun \& Lee, 2008; Jeong \& Ji, 2014; Lazarus \& Folkman, 1984). Therefore, it is necessary to examine the relationship between psychological factors dealing with stress and the PITR test.

There is another issue regarding the PITR research in terms of applying the results to the clinical field. Most prior studies reached their conclusions based on the following approach to data analysis. Researchers divided the upper and lower groups according to subjects' psychological characteristics and compared the drawings of the two groups (Chung, 2018; Jeong \& Kim, 2008; Kang \& Lee, 2014; Kim, 2017; Kim, Lee, \& Woo, 2013; Kwon, Kim, \& Song, 2016; Lee \& Lee, 2014). A few studies examined the relationship in the opposite direction (Chung, 2012; Yoo, 2013). However, no single study attempted to verify the relationship in both directions simultaneously.

It would be desirable to gather all empirical data in both directions to interpret the picture test results (see Figure 1). This is because the basic principle of the proposition "If A, then B" does not necessarily guarantee that "If B, then A." In a clinical setting, clients' pictures will be used to estimate the inner state of their psychology, so the results in direction (2) are an important and necessary form of empirical data.

This study will examine the relationship between drawing test responses and psychological characteristics in both directions. For direction (1), the study examines the differences in the drawing test responses according to subjects' psychological characteristics. For direction (2), the study investigates the differences in subjects' psychological characteristics based on the drawing test results. If 


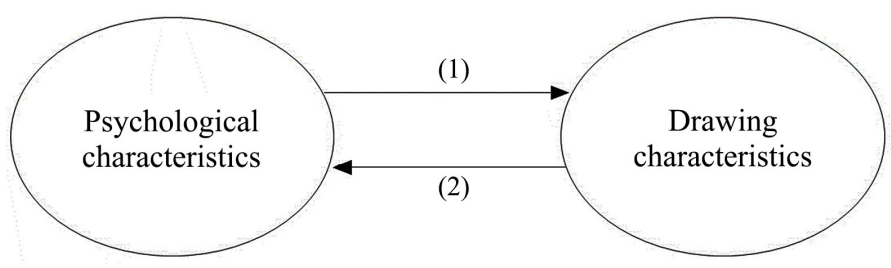

Figure 1. A method of verifying the relationship between the picture test and psychological attributes. (1) drawing test response differences based on psychological characteristics; (2) differences in psychological characteristics based on drawing test results.

both (1) and (2) produce significant results, we will have more reliable empirical evidence in picture analysis.

The reason why not many studies have examined direction (2) is that too many variables must be controlled. Being able to study individuals' responses in as homogeneous an environment as possible would be ideal. In the context of uniformly stressed environments, the usefulness of the PITR test as a psychological tool to distinguish individuals who cope well with stress from those who do not takes the results of previous studies a step further. In this study, we chose the military as a highly stressful environment and conducted research on the rank-and-file individuals who perform military service obligations.

The military is characterized by strict order, intense training, and an inflexible organizational culture. Rank-and-file individuals who obligatorily become soldiers must leave home and live in military barracks, with little access to any private spaces during their service period. Thus, they can experience considerable stress, which is officially called military service stress. Studies have found that military service stress is the main cause of soldiers' mental health deterioration and that many of the harmful accidents that occur in the army are due to this type of stress (Park \& Jeon, 2013; Park \& Lee, 2014; Pietrzak, Pullman, Cotea, \& Nasveld, 2012). Although military service stress is a threat to mental health and successful adjustment, the negative effects of stress do not impact every rank-in-file individual the same way. Individual factors that play a role in stress and the influence of stress itself vary from person to person.

Resilience is an important personal quality that can help individuals cope with stress (Connor \& Davidson, 2003). Resilience is defined as individuals' ability to recover quickly from dangerous or traumatic experiences and adjust successfully (Werner \& Smith, 1992). From a personal point of view, resilience refers to the ability of an individual facing adversity to adapt to the situation and achieve growth after adversity. Tusaie \& Dyer (2004) suggested that it is the ability to recover from stress-and to be able to function better than average even under stress-that is crucial for adjustment. Resilience is described as a foundation that can help individuals effectively cope with stress, increase their work efficiency, and enable them to perform their jobs more successfully.

Resilience is a composite notion that combines several concepts. One of its constructs is psychological hardiness (Connor \& Davidson, 2003). In particular, 
Bartone, Roland, Picano, \& Williams (2008) stressed the importance of psychological hardiness for Army Special Forces candidates. Soldiers with high psychological hardiness are typically well-suited to the military, as their willingness and ability to engage in combat is often high. Another study also found that a high degree of hardiness positively affects soldiers' mental health (Zakin, Solomon, \& Neria, 2003). In addition, Seol (2018) discovered that psychological hardiness mediated the effect of military stress on mental health.

Optimism is another factor within resilience that is also important for military life adjustment. Optimistic soldiers are more likely to adapt well to military life, and optimism has been identified as a mediator of military life stress and adjustment (Oh, Park, Lee, \& Kwon, 2013).

While resilience is a psychological mechanism that deals with stress, the influence of stress can be examined comprehensively in the context of military life adjustment. Military life stress has a negative impact on military life adjustment, as many prior studies have demonstrated (Hyun, Chung, \& Kang, 2009; Koo, 2004; Shelef, Klomek, Yavnai, \& Shahar, 2017; Son, 2001; Song, 2013; Yeon \& Moon, 2018). In recent times, soldiers' military maladjustment has been acknowledged as an important issue that must be resolved. Serious maladjustment problems, such as firearms accidents, beatings in the military, desertion, and relationship conflicts are reported (Ahn, Sohn, Lee, \& Seo, 2007; Jung \& Lee, 2008). It should be noted that military life stress interacts with individuals' values, stress coping styles, and perceptions of their environment, ultimately affecting their military life adjustment (Jeong \& Ji, 2014; Koo, 2004).

Therefore, if we can assess individuals' stress experiences and coping abilities through various methods, it would be possible to prevent this problem and/or cope with it adequately. This study will examine the PITR test's effectiveness to assess the degree of adjustment and resilience of rank-and-file individuals who were obligated to become soldiers. The study addresses three specific research questions, as follows:

Research question 1. Is there a difference in the response characteristics of the PITR test depending on soldiers' level of military life adjustment?

Research question 2. Is there a difference in the response characteristics of the PITR test depending on soldiers' level of resilience?

Research question 3. Is there a difference in military adjustment and resilience depending on the PITR coping capacity level?

\section{Method}

\subsection{Participants}

In total, 300 soldiers participated in the study. After omitting 15 incomplete responses, 285 data were included in the analysis. All subjects were male, and their mean age was 20.99 years (S.D. $=1.36$ ). The marital status distribution was 99.0\% single and $1.0 \%$ married. Participants' education level distribution was as follows: $22.7 \%$ graduated from high school, $71.6 \%$ were enrolled in college, and 
$5.4 \%$ graduated from college. Their socioeconomic status varied as follows: $5.4 \%$ upper class, $15.8 \%$ upper middle class, $65.5 \%$ middle class, $11.2 \%$ working class, and $2.2 \%$ poor. Participants' average service period at the time of participation was 11.18 months, ranging from one month to 20 months (S.D. $=5.37$ ).

\subsection{Procedure and Ethical Considerations}

We first reported the research plan to the Army Headquarters of South Korea and obtained approval. We also obtained IRB approval from the researcher's institution. Then, the researchers visited each army unit to explain the purpose of the research, the contents of the questionnaire, the characteristics of the testing tool, and the implementation method. The participants were clearly informed that they would not be penalized even if they did not participate in the survey or quit at any point. After introducing the test procedure to ensure participants' voluntary participation and anonymity, the researcher and the commander left the test site. When participants completed the questionnaire, they placed their responses in the collection box.

\subsection{Measures}

The Military Life Adjustment Scale. In order to measure soldiers' military life adjustment, this study used the Military Life Adjustment Scale originally developed by Stauffer, Suchman, Devinney, Star, \& Williams (1949) but modified by Koo (2004) to fit the context of the Korean military. This scale features four sub-scales including stability of mind and body, willingness to perform the assigned mission, job satisfaction, and positive attitude toward the military organization. It is composed of 26 total items that are rated on a five-point Likert scale. The higher the final scores, the better the soldiers' adjustment to military life. The Cronbach's a was 0.93 in Koo's (2004) study and 0.94 in this study.

The Resilience Scale. The Resilience Scale was developed by Connor \& Davidson (2003) and it was translated and validated by Baek, Lee, Joo, Lee, \& Choi (2010). It is composed of 25 total items in five domains including psychological hardiness, tolerance, positivity, controllability, and spiritual belief. Each item is rated on a five-point Likert scale ranging from 0 points (not true at all) to 4 points (true nearly all of the time). The scale's total score ranges from 0 to 100 , with higher scores reflecting greater resilience. Connor \& Davidson (2003) reported the Cronbach's $\alpha$ as 0.93 while the present study found it to be 0.91 .

The Person-in-the-Rain Drawing Test. The original idea of PITR appeared in Abrams and Amchin (Hammer, 1958), with the simple instruction of drawing a person in rain. The materials for the test include $210 \times 297 \mathrm{~mm}$ white paper, pencils, and erasers. This study used Lack's PITR scoring scale (1996), which was translated into Korean and validated by Son (2004). The rating scale has 35 items divided into two domains: the Stress area (S1 to S16) and the Resource area (R1 to R19). There are three evaluation scales: the Stress Scale, the Resource Scale, and the Coping Capacity Index score. The stress score is the sum of 16 stress 
items. The resource score is calculated using two sub-scales: $(\mathrm{R} 1+\mathrm{R} 2+\ldots+$ $\mathrm{R} 16)-(\mathrm{R} 17+\mathrm{R} 18+\mathrm{R} 19)$. The coping capacity score is calculated by subtracting the stress score from the resource score. The higher the sum score, the stronger the attributes being measured. In this study, two art therapists performed the scoring. The interrater reliability was $0.89-1.00$.

\subsection{Analysis Method}

The data collected in this study were analyzed using SPSS 21.0. First, we calculated the frequency and percentage of the soldiers' general characteristics. The Cronbach's a was calculated to measure the reliability of the study's tests, and the Pearson's correlation coefficient was calculated between the raters. The mean and standard deviation were calculated to divide the groups based on the level of military life adjustment, resilience, and PITR Coping Capacity Index score. After creating one high group and one low group, an independent t-test was performed to compare responses between the two groups.

\section{Results}

\subsection{Comparison of Group Composition}

The group classification according to degree of military life adjustment is as follows. The Military Life Adjustment Scale uses a mean score as a final score, which ranges from 1 to 5 points. In the present study, the mean of all participants was 3.16 while the standard deviation was 0.79 . Respondents who received a score less than one standard deviation from the mean were placed in the lower group $(N=37,12.9 \%)$, whereas respondents who received a score higher than one standard deviation from the average were placed in the higher group $(N=$ $46,16.1 \%)$. The mean score of the higher group was $4.42(S . D .=0.33)$ and the mean score of the lower group was $1.95($ S.D. $=0.34)$. There was no significant difference between the two groups in terms of age, marital status, or service period.

The group composition based on the level of resilience was conducted in the same manner. The Resilience Scale score ranged from 0 to 100, and the mean resilience of all participants was $66.70($ S.D. $=18.05)$. The higher group consisted of 58 soldiers $(20.4 \%)$ and the lower group consisted of 41 soldiers (14.4\%). The mean of the higher group was $92.38(S . D .=5.15)$ while the mean of the lower group was $38.81($ S.D. $=9.90)$. There was no significant difference in age, service period, or marital status between the two groups.

The group composition according to the PITR was based on the PITR Coping Capacity Index score. Participants' coping capacity mean score was -1.77 $(S . D .=5.34)$. The higher group consisted of 49 soldiers $(17.2 \%)$ and the lower group of 47 soldiers (16.5\%). The mean score of the higher group was 5.88 (S.D. $=1.79)$ and the mean score of the lower group was $-10.15($ S.D. $=2.10)$. The two groups also showed no difference in terms of age, service period, or marital status. 


\subsection{Comparison of the PITR Results Based on Military Life Adjustment Level}

Table 1 presents the comparison results of the PITR responses between the two groups. The higher adjustment group had a mean value of $4.93($ S.D. $=2.19)$ on the PITR Stress Scale while the lower group had a mean of 5.68 points (S.D. = 2.11). The mean difference between the two groups was not significant, $t(81)=$ $1.56, p=0.12$. In terms of the Resource subscale, which adds up R1 to R16, the mean was $8.43(S . D .=2.61)$ for the higher adjustment group and 6.84 (S.D. = 3.03) for the lower group. This difference between the two groups was statistically significant, $t(81)=2.58, p<0.05$. When examining the total resource score, the mean score of the higher adjustment group was $4.20(S . D .=4.55)$ and the mean score of the lower group was $2.30($ S.D. $=4.74)$. The difference between the two groups exhibited a trend toward a significant difference, $t(81)=1.86, p=$ 0.07. Finally, the Coping capacity score-which was calculated by subtracting the stress index from the resource index-showed a significant difference between the two groups, $t(81)=2.17, p<0.05$.

Appendice A and Appendice B present the frequency of each PITR item. Item S3, the excessive rain item, showed a difference in response frequency between the two groups according to the level of military life adjustment. Furthermore, the higher adjustment group had a higher ratio of drawing protective gear and/or an umbrella than the lower group. The size of the protective gear was also big enough to protect the person from rain, and the gear was undamaged and well-defined in its intact form. However, little difference was found in the frequency of the person's expression. Both groups hardly drew raincoats, rain hats, or rain boots. In both groups, the percentage of drawing a stick figure was about half while the percentage of drawing an obscured or sideways face was less than $50 \%$. There was no difference between the two groups in terms of the person's size, the portrayal of the entire person, and the line quality. Finally, the two groups exhibited little difference in the frequency of omitting body parts, and both groups rarely drew teeth on the figures.

\subsection{Comparison of PITR Results Based on Resilience Level}

Table 2 shows the comparison results of soldiers' PITR stress responses between both groups based on the level of resilience. There was no difference between the two groups in terms of the PITR Stress Index. However, the Resource subscales uncovered a significant difference between the two groups, $t(96)=2.26, p<0.05$. The mean of the higher resilience group was $8.07(S . D .=2.52)$ while it was 6.80 $(S . D .=3.01)$ for the lower resilience group. In addition, the total resource score showed a trend toward a significant difference, $t(96)=1.89, p=0.06$.

Regarding the Coping capacity score results, the higher resilience group had a mean of $-1.11(S . D .=4.54)$ while the lower group had a mean of -3.03 (S.D. $=$ 5.53). The comparison between the two groups showed a trend toward a significant difference, $t(96)=1.87, p=0.06$. 
Table 1. Comparison of the PITR based on military life adjustment level.

\begin{tabular}{ccccc}
\hline \multirow{2}{*}{ Item } & Content & \multicolumn{2}{c}{ Means (S.D.) } & \multirow{2}{*}{$t$} \\
\cline { 3 - 4 } & & $\begin{array}{c}\text { Lower Group } \\
(N=37)\end{array}$ & $\begin{array}{c}\text { Upper Group } \\
(N=46)\end{array}$ & \\
\hline \multirow{2}{*}{ Stress score } & Sum of S1 to S16 & 5.68 & 4.93 & -1.56 \\
& & $(2.11)$ & $(2.19)$ & \\
Resource subtotal & Sum of R1 to R16 & 6.84 & 8.43 & \multirow{2}{*}{$2.58^{*}$} \\
& & $(3.03)$ & $(2.61)$ & \\
Resource score & (Resource subtotal) & 2.29 & 4.20 & \multirow{2}{*}{$1.86^{+}$} \\
Coping capacity & (Sum of R17 to R19) & $(4.74)$ & $(4.55)$ & \\
score & (Resource score) & -3.38 & -0.74 & $2.17^{*}$ \\
\hline
\end{tabular}

${ }^{+} p<0.10,{ }^{*} p<0.05$.

Table 2. Comparison of the PITR based on resilience level.

\begin{tabular}{|c|c|c|c|c|}
\hline \multirow[b]{2}{*}{ Item } & \multirow[b]{2}{*}{ Content } & \multicolumn{2}{|c|}{ Means (S.D.) } & \multirow[b]{2}{*}{$t$} \\
\hline & & $\begin{array}{l}\text { Lower Group } \\
\qquad(N=41)\end{array}$ & $\begin{array}{l}\text { Upper Group } \\
\qquad(N=57)\end{array}$ & \\
\hline Stress score & Sum of $S 1$ to $S 16$ & $\begin{array}{c}5.07 \\
(2.13)\end{array}$ & $\begin{array}{c}4.86 \\
(1.89)\end{array}$ & -0.52 \\
\hline Resource subtotal & Sum of R1 to R16 & $\begin{array}{c}6.80 \\
(3.01)\end{array}$ & $\begin{array}{c}8.07 \\
(2.52)\end{array}$ & $2.26^{*}$ \\
\hline Resource score & $\begin{array}{l}\text { (Resource subtotal) - } \\
\text { (Sum of R17 to R19) }\end{array}$ & $\begin{array}{c}2.10 \\
(4.43)\end{array}$ & $\begin{array}{c}3.75 \\
(4.11)\end{array}$ & $1.89^{+}$ \\
\hline Coping capacity score & $\begin{array}{c}\text { (Resource score) - } \\
\text { (Stress score) }\end{array}$ & $\begin{array}{l}-3.03 \\
(5.53)\end{array}$ & $\begin{array}{l}-1.11 \\
(4.54)\end{array}$ & $1.87^{+}$ \\
\hline
\end{tabular}

${ }^{+} p<0.10,{ }^{*} p<0.05$.

Appendice A and Appendice B present the results of the individual items' responses. There was a significant difference between the two groups in the expression of excessive rain, S3. Among the detailed resource items, the higher resilience group exhibited a higher rate of drawing people in the center than the lower resilience group.

\subsection{Comparison of Military Life Adjustment and Resilience Based on the PITR Coping Capacity Score}

Using the PITR test's Coping capacity score, we divided participants into a higher group (49 individuals) and a lower group (47 individuals). Table 3 presents the comparison results between the two groups. First, there was a significant difference in total military life adjustment, $t(94)=2.65, p<0.01$. Comparing the sub-items, there were significant differences between the two groups in terms of stability, job satisfaction, and positive attitude, as follows: $t(94)=$ $3.18, p<0.01 ; t(94)=2.25, p<0.05 ; t(94)=2.51, p<0.05$. More specifically, the soldiers in the group with the higher PITR Coping capacity score had better mental/physical stability, higher job satisfaction, and a more positive attitude than soldiers in the lower group. 
Table 3. Comparison of military life adjustment and resiliencebased on the PITR Coping capacity score.

\begin{tabular}{cccc}
\hline \multirow{2}{*}{ Scale } & \multicolumn{2}{c}{ Means (S.D.) } & \multirow{2}{*}{$t$} \\
\cline { 2 - 3 } & $\begin{array}{c}\text { Lower Group } \\
(N=47)\end{array}$ & $\begin{array}{c}\text { Upper Group } \\
(N=49)\end{array}$ & \\
\hline Adjustment during Army Life & $2.87(0.80)$ & $3.32(0.86)$ & $2.65^{* *}$ \\
Mental/Physical Stability & $3.28(0.91)$ & $3.81(0.73)$ & $3.18^{* *}$ \\
Mission Commitment & $2.44(1.23)$ & $2.86(1.27)$ & 1.65 \\
Job Satisfaction & $3.03(0.91)$ & $3.46(0.98)$ & $2.25^{*}$ \\
Positive Attitude & $2.79(0.82)$ & $3.24(0.93)$ & $2.51^{*}$ \\
Resilience & $61.81(18.04)$ & $70.69(18.34)$ & $2.39^{*}$ \\
CD-RISC 1 & $19.36(6.52)$ & $22.57(6.51)$ & $2.41^{*}$ \\
CD-RISC 2 & $16.66(5.26)$ & $19.00(5.74)$ & $2.08^{*}$ \\
CD-RISC 3 & $13.57(4.27)$ & $15.27(3.76)$ & $2.06^{*}$ \\
CD-RISC 4 & $7.87(2.48)$ & $9.00(2.04)$ & $2.44^{*}$ \\
CD-RISC 5 & $4.34(1.86)$ & $4.86(2.04)$ & 1.30 \\
\hline
\end{tabular}

${ }^{*} p<0.05,{ }^{* *} p<0.01$. Note. CD-RISC 1: Personal competence, high standards, tenacity.CD-RISC 2: Trust in one's instincts, tolerance of negative affect, strengthening effects of stress.CD-RISC 3: Positive acceptance of change, secure relationships.CD-RISC 4: Control.CD-RISC 5: Spiritual influences.

Comparing the resilience results, the higher PITR Coping capacity group exhibited a significantly higher resilience score than the lower PITR group, $t(94)=$ $2.39, p<0.05$. In addition, there was a significant difference in all sub-items except for spiritual influences, as follows: $t(94)=2.41, p<0.05 ; t(94)=2.08, p<$ $0.05 ; t(94)=2.06, p<0.05 ; t(94)=2.44, p<0.05$.

\section{Discussion and Conclusion}

The purpose of this study was to investigate the utility of PITR as a tool for assessing adjustment and resilience. The study's findings and implications are as follows.

First, the present study employed a two-way verification method: it used respondents' psychological attributes to clarify the characteristics of the picture test's responses, and vice versa. Thus, this study satisfies the conditions of both "If $A$, then $B$ " and "If $B$, then A." In doing so, the study provides empirical evidence for the interpretation of art assessments in the clinical field. In clinical settings, therapists often estimate individuals' psychological state based on the pictures they draw. More often than not, therapists rely on empirical evidence including anecdotal case reports as a basis for their interpretations. As discussed in the introduction, prior research materials used as empirical evidence have been mostly quantitative studies that examined the differences in art assessment responses based on the differences in individuals' psychological properties. How- 
ever, strictly speaking, quantitative research used as a basis for interpretation should provide evidence of the differences in psychological states derived from the picture response characteristics. This study meets these conditions while employing the same method from previous research, giving credibility to the results of this study as empirical data that can be applied in the clinical field.

Second, the differences in the PITR responses based on the adjustment and resilience levels were more evident in drawing resources rather than in expressing stress. There are two possible explanations for this: 1) the two indicators differ in their discriminatory power; or 2) the psychological attributes we evaluated produce differences mainly in internal resources, not in external circumstances. In this study, the first explanation was rejected because both scales showed significant results in a large number of previous studies (Chung, 2018; Kang \& Lee, 2014; Kim, 2017; Kim, Lee, \& Woo, 2013; Kwon, Kim, \& Song, 2016; Lee \& Lee, 2014). The second explanation concurs with Lee and Kim's (2016) observation. The researchers examined the relationship between personality traits and PITR responses and found that the five personality traits were more related to the resource index than the stress index in the PITR. These findings suggest that the PITR stress index represents external situations while the resource index is better suited to represent internal psychological characteristics.

In terms of the second explanation, we may consider a specific definition of the concept of "resilience." Gucciardi, Jackson, Coulter, \& Mallett (2011) pointed out that resilience has two main aspects: "exposure to significant risk or adversity and the attainment of positive adjustment or competence" (p. 423). According to this definition, adversity or danger exists for people with high resilience. This explains why people with high resilience included many stress symbols when drawing the PITR. Thus, there was little difference between the two groups in the stress index comparison and significant difference between the groups in the resource index comparison.

Previous studies examining individuals who experienced adjustment problems in a stressful environment, such as the military, reported that individuals' coping resources and ability to deal with stress were more important than the actual stress they experienced (Choi \& Kim, 2015; Hyun \& Lee, 2008; Kim \& Ha, 2013; Lee \& Kim, 2015; Lee \& Park, 2012; Seol, 2018). In other words, the presence of external stress does not have the same effect on all soldiers, and there are various psychosocial mediating variables between stress and its consequences in terms of psychological, behavioral, and/or health problems. Negative influences can be buffered by psychological variables that mediate stress. Therefore, this might explain why the coping resources represented by the umbrella or other protective gear showed a more significant difference than the stress itself, which was represented as rain in the drawings. This finding confirms once again that, in terms of adjustment, it is more important to have a sufficient coping capacity rather than to have small amounts of external stress.

Third, we found significant differences in military life adjustment and resi- 
lience between the upper and lower groups based on the PITR coping capacity score. These results provide valuable data and implications that can be applied in clinical settings.

Fourth, in terms of coping resources, the most important feature in the drawings was the presence of some form of protection against the rain, such as an umbrella. The drawings made by the lower army life adjustment group had lower rates of these protections. Even if protective gear was drawn, its suitability was low; e.g., it was not large enough to protect a person from the rain, or the umbrella was not working properly. This is consistent with the results of previous research. For instance, Lee \& Lee (2014) reported that highly stressed military officers tend to draw protective gear of inadequate sizes, while Kwon, Kim, \& Song (2016) found that stressed nurses tend to draw people holding their umbrellas improperly.

The most evident stress image expressed in the PITR was the amount of rain. For this, the same findings were reported in prior research. For example, Kim (2017) explored the relationship between athletes' stress level and PITR response, reporting that the higher the level of stress, the higher the amount of rain. Jeong \& Kim (2008) found that middle school students with high academic stress drew significantly greater amounts of rain in the PITR. Kwon, Kim, \& Song (2016) examined the relationship between nurses' stress level and PITR response and confirmed significant differences in the amount of rain based on stress.

While some items have shown consistent results in terms of determining differences, other items have shown inconsistent results. For instance, according to previous research, the amount of clouds item has been inconsistent in differentiating the expression of stress. Some studies have reported that clouds appear more often in the drawings of stressed participants (Kang \& Lee, 2014; Lee \& Lee, 2014), while other studies found no difference based on the amount of clouds (Chung, 2018; Jeong \& Kim, 2008; Kim, 2017; Kim, Lee, \& Woo, 2013; Kwon, Kim, \& Song, 2016). We found only a few cases where clouds were drawn in the PITR of soldiers with low adjustment, and our data features a table clarifying that the presence of clouds does not reveal any difference.

It is important to note that many individual items in this study exhibited no difference between groups. Individual items by themselves were not enough to distinguish groups. The PITR Coping Capacity Index, which featured some distinguishing power, was a combination of 16 stress items and 19 resource items. Therefore, it is worthwhile to emphasize the benefit of considering various factors simultaneously to produce valid interpretations.

The study's limitations and suggestions for future research are as follows. First, since this study focused on soldiers, the ability to generalize its results to other situations and contexts is limited. Second, the concept of resilience discussed in this study can be further developed. The question of how to increase resilience for soldiers who have little of it remains a challenge. 


\section{Fund}

This research was supported by the National Research Foundation of Korea (NRF) grant funded by the Korea government (MSIT) (No. 2018R1A5A7025522).

\section{Conflicts of Interest}

The authors declare no conflicts of interest regarding the publication of this paper.

\section{References}

Ahn, H., Sohn, N., Lee, M., \& Seo, E. (2007). Military Adjustment among Korean Servicemen and Its Relation to Human Rights Violation Experiences. The Korea Journal of Counseling, 8, 425-435. https://doi.org/10.15703/kjc.8.2.200706.425

Baek, H. S., Lee, K. U., Joo, E. J., Lee, M. Y., \& Choi, K. S. (2010). Reliability and Validity of the Korean Version of the Connor-Davidson Resilience Scale. Psychiatry Investigation, 7, 109-115. https://doi.org/10.4306/pi.2010.7.2.109

Bartone, P., Kelly, D. R., \& Matthews, M. E. (2013). Psychological Hardiness Predicts Adaptability in Military Leaders: A Prospective Study. International Journal of Selection and Assessment, 21, 200-210. https://doi.org/10.1111/ijsa.12029

Bartone, P., Roland, R., Picano, J., \& Williams, T. J. (2008). Psychological Hardiness Predicts Success in US Army Special Forces Candidates. International Journal of Selection and Assessment, 16, 78-81. https://doi.org/10.1111/j.1468-2389.2008.00412.x

Brooke, S. (2004). Tools of the Trade. (2nd ed.). New York: Charles C Thomas.

Choi, K., \& Kim, C. (2015). The Effect of Stress Management Program for Maladjusted Soldiers. Korean Academy of Military Social Welfare, 8, 69-103.

Chung, K. (2012). 'The Person in the Rain' Drawing Response Characteristics and Ways of Stress Coping in College Students. Korean Journal of Art Therapy, 19, 1029-1044.

Chung, Y. (2018). A Study on the Possibility of Using the PITR (Person in the Rain) as a Smartphone Addiction Screening Tool for Adolescents. Korean Journal of Educational Therapies, 10, 111-131. https://doi.org/10.35185/KJET.10.1.7

Connor, K. M., \& Davidson, J. (2003). Development of a New Resilience Scale: The Connor-Davidson Resilience Scale (CD-RISC). Depression and Anxiety, 18, 76-83. https://doi.org/10.1002/da.10113

Gucciardi, D. F., Jackson, B., Coulter, T. J., \& Mallett, C. J. (2011). The Connor-Davidson Resilience Scale (CD-RISC): Dimensionality and Age-Related Measurement Invariance with Australian Cricketers. Psychology of Sport and Exercise, 12, 423-433. https://doi.org/10.1016/j.psychsport.2011.02.005

Hammer, E. F. (1958). The Clinical Application of Projective Drawings. Springfield, IL: Charles C Thomas.

Hyun, H. S., \& Lee, I. S. (2008). A Study on Stress and Symptoms of Stress in Solders in the Army. Journal of Korean Academy of Nursing, 38, 238-247. https://doi.org/10.4040/jkan.2008.38.2.238

Hyun, M. S., Chung, H. I., \& Kang, H. S. (2009). Influencing Factors on Military Adaptation among Korean Soldiers. Journal of Korean Academy of Psychiatric and Mental Health Nursing, 18, 305-312.

Jeong, E., \& Kim, G. (2008). Relationship of Academic Stress in Middle School and PITR Responses. Journal of Korean Home Management Association, 26, 71-81. 
Jeong, W. C., \& Ji, H. S. (2014). Moderating Effects of Ego-Resilience on the Relationship between Military Life Stress and Military Adjustment of Soldier. The Journal of the Korea Contents Association, 14, 311-310. https://doi.org/10.5392/JKCA.2014.14.09.311

Jue, J., \& Kim, T. E. (2011). Female High School Students' Juvenile Delinquency and Anger in the Person in the Rain Test. Art Education Research Review, 25, 217-240.

Jung, W., \& Lee, C. (2008). A Study on the Predictive Factors of Desertion from the Military Services. Social Science Research, 17, 2-18.

Kang, H., \& Lee, K. (2014). A Study on the Response Characteristic of 'Person in the Rain' Drawing Test Based on the Level of Job Stress of Elementary School Teacher. Korean Journal of Art Therapy, 21, 681-700.

Kim, M., Lee, K., \& Woo, J. (2013). The Response Characteristic of 'the Person in the Rain' Drawing Based on the Level of Job Stress of Nurses. Korean Journal of Art Therapy, 20, 479-496.

Kim, S. (2011). Response Characteristic of "Person in the Rain" Drawing Test on Post-Traumatic Stress and Depression of North Korean Refugees. Unpublished Master's Thesis, Gyeongsan, South Korea: Daegu University.

Kim, S. M. (2017). Different Responses in "Person in the Rain” Drawing Test According to Stress and Depression Level in University Athletes. Korean Journal of Art Therapy, 24, 197-223.

Kim, S., \& Ha, Y. (2013). Influencing Factors on Perceived Stress and Mental Health among Army Soldiers. Journal of Military Nursing Research, 31, 31-41.

Koo, S. S. (2004). A Study on Adjustment in Military Life of the New Generation Soldier. Unpublished Doctoral Dissertation, SSeodaemun, Seoul: Ewha Woman's University.

Krom, C. P. (2002). Hospice Nurses and the Palliative Care Environment: Indicators of Stress and Coping in the Draw-a-Person-in-the-Rain Test. Unpublished Master's Thesis, New Haven, CT: Albertus Magnus College.

Kwon, H. J., Kim, S. K., \& Song, D. H. (2016). The Characteristics of Responses to DAPR (Draw-a-Person-in-the-Rain) Assessment Based on the Level of Stress Response, Self-Efficacy of Nurses. The Journal of the Korean Association of Psychotherapy, 8, 81-111.

Lack, H. (1996). The Person-in-the-Rain Projective Drawing as a Measure of Children's Coping Capacity: A Concurrent Validity Study Using Rorschach, Psychiatric and Life History Variables. Unpublished Doctoral Dissertation, Los Angeles|CA: The California School of Professional Psychology.

Lazarus, R. S., \& Folkman, S. (1984). Stress, Appraisal, and Coping. New York: Springer Publishing Company.

Lee, J. H., \& Kim, J. K. (2015). Effects of Self-Esteem, Locus of Control to Military Life on Soldiers Adjusting: Mediating Effect of Social Support and Stress Coping Strategies. The Korean Journal of Culture and Social Issues, 21, 299-315. https://doi.org/10.20406/kjcs.2015.08.21.3.299

Lee, J. Y., \& Park, Y. H. (2012). Soldier Stress and Health Promotion Behavior of Soldiers in Specific Environment (GOP, GP). Journal of Military Nursing Research, 30, 44-59.

Lee, M. K. (2006). On Elementary School Kids' Stress, Stress Coping Behavior, and Reactive Characteristics to the Person-in-the-Rain Test. Unpublished Master's Thesis, Gyeongsan, South Korea: Yeungnam University.

Lee, O. K., Kim, G. S. (2016). A Study on the Relationship between Character Traits of NEO and Response Characteristics of DAPR Drawn by Upper Grade Elementary School Students. Journal of Arts Psychotherapy, 12, 151-171. 
Lee, S. H., \& Lee, K. M. (2014). A Study on the Relation between Response Characteristics in Person-in-the-Rain Drawing Test and Non-Commissioned Officers' Job Stress Level. Journal of Arts Psychotherapy, 10, 39-62.

Oh, M. J., Park, H. H., Lee, J. H., \& Kwon, J. H. (2013). The Moderating Effect of Optimism on the Relationship between Military Life Stress and Adjustment of Soldiers. Korean Journal of Counseling, 14, 1051-1065.

Park, H. Y., \& Jeon, C. H. (2013). The Effects of Stress-Coping Styles of Navy on the Prevention of Military Crimes. Korean Journal of Scientific Criminal Investigation, 7, 214-226.

Park, S. I., \& Lee, D. G. (2014). Influence of Job Satisfaction, Job Stress, Anger Expression, Depression, and Hopelessness of Junior Officers of Armed Forces on Their Suicidal Ideation. The Korean Journal of Counseling and Psychotherapy, 26, 545-571. https://doi.org/10.15703/kjc.14.2.201304.1051

Pietrzak, E., Pullman, S., Cotea, C., \& Nasveld, P. (2012). Effects of Deployment on Mental Health in Modern Military Forces: A Review of Longitudinal Studies. Journal of Military and Veterans Health, 20, 24-36.

Russo, A. (2007). The Draw-a-Person-in-the-Rain Technique to Assess Stress in Elementary School Professionals. Unpublished Master's Thesis, New Haven, CT: Albertus Magnus College.

Seol, J. H. (2018). The Role of Psychological Hardiness and Social Support between Stress and Mental Health among Military Personnel: A Mediated Moderation Analysis. The Korean Journal of Health Psychology, 23, 57-79. https://doi.org/10.17315/kjhp.2018.23.1.004

Shelef, L., Klomek, A. B., Yavnai, N., \& Shahar, G. (2017). Perceived Stress and Intent to Die in Young Soldiers Who Attempt Suicide. Crisis, 39, 144-148. https://doi.org/10.1027/0227-5910/a000481

Son, H. R. (2001). A Study on How Stress Affects Soldiers of New Generations in Adjusting to the Military. Unpublished Master's Thesis, Seodaemun-gu, Seoul: Yonsei University.

Son, M. (2004). The Study about Stress and Coping Behavior of Elementary School Students with PITR. Unpublished Doctoral Dissertation, Busan, South Korea: Kyungsung University.

Son, M. (2007). Research on Measuring of Stress and Coping Behavior of Elementary Students through Drawing of People in the Rain (PITR). Korean Journal of Art Therapy, 14, 649-668.

Song, H. J. (2013). Psychological Autopsy of Military Suicide: Based on Navy Personnel. Korean Journal of Scientific Criminal Investigation, 7, 126-137.

Stauffer, S. A., Suchman, E. A., Devinney, L. C., Star, S. A., \& Williams, R. M. (1949). The American Soldiers: Adjustment during Army Life. Princeton, NJ: Princeton University Press.

Tusaie, K., \& Dyer, J. (2004). Resilience: A Historical Review of the Construct. Holistic Nursing Practice, 18, 3-8. https://doi.org/10.1097/00004650-200401000-00002

Werner, E. E., \& Smith, R. S. (1992). Overcoming Odds: High Risk Children from Birth to Adulthood. Ithaca, NY: Cornell University Press.

Willis, L. R., Joy, S. P., \& Kaiser, D. H. (2010). Draw-a-Person-in-the-Rain as an Assessment of Stress and Coping Resources. The Arts in Psychotherapy, 37, 233-239. https://doi.org/10.1016/j.aip.2010.04.009

Yang, W., \& Won, H. (2013). An Analysis of Correlation of High School Students' Stress 
from College-Bound Study, Depression, and Suicidal Thoughts with Their Person-inthe-Rain Drawings. Korean Journal of Art Therapy, 20, 263-283.

Yeon, M. S., \& Moon, J. W. (2018). The Influence of Soldiers' Stress on Military Life Adaptation: Focusing on the Moderating Effects of Resilience and Social Support. Korean Academy of Military Social Welfare, 11, 5-24.

Yoo, K. M. (2013). A Research on DAPR's Effect on College Students' Resilience, Stress, Coping Resources, and Ability. Journal of Arts Psychotherapy, 9, 97-120.

Zakin, G., Solomon, Z., \& Neria, Y. (2003). Hardiness, Attachment Style, and Long-Term Psychological Distress among Israeli POWs and Combat Veterans. Personality and Individual Differences, 34, 819-829. https://doi.org/10.1016/S0191-8869(02)00073-9 
Appendix A. The PITR Stress Index results based on military life adjustment level and resilience level.

\begin{tabular}{|c|c|c|c|c|c|c|}
\hline & \multirow{3}{*}{ Item } & \multirow{3}{*}{ Content } & \multicolumn{4}{|c|}{ Frequency } \\
\hline & & & \multicolumn{2}{|c|}{$\begin{array}{l}\text { Military Life } \\
\text { Adjustment }\end{array}$} & \multicolumn{2}{|c|}{ Resilience } \\
\hline & & & $\begin{array}{l}\text { Lower } \\
\text { Group } \\
(N=37)\end{array}$ & $\begin{array}{l}\text { Upper } \\
\text { Group } \\
(N=46)\end{array}$ & $\begin{array}{l}\text { Lower } \\
\text { Group } \\
(N=41)\end{array}$ & $\begin{array}{l}\text { Upper } \\
\text { Group } \\
(N=57)\end{array}$ \\
\hline S1 & No rain & $\begin{array}{l}\text { Rain is present } \\
\text { No rain or other } \\
\text { precipitation }\end{array}$ & $\begin{array}{l}37 \\
0\end{array}$ & $\begin{array}{l}44 \\
2\end{array}$ & $\begin{array}{l}39 \\
2\end{array}$ & $\begin{array}{l}56 \\
1\end{array}$ \\
\hline S2 & Rain Present & $\begin{array}{l}\text { Rain is absent } \\
\text { Rain/precipitation is present }\end{array}$ & $\begin{array}{l}0 \\
37\end{array}$ & $\begin{array}{l}0 \\
44\end{array}$ & $\begin{array}{l}0 \\
39\end{array}$ & $\begin{array}{l}0 \\
56\end{array}$ \\
\hline S3 & Excess rain & $\begin{array}{l}\text { Rain space }<1.5 \times \text { person space } \\
\text { Rain space }>1.5 \times \text { person space }\end{array}$ & $\begin{array}{l}8 \\
29\end{array}$ & $\begin{array}{l}19 \\
25\end{array}$ & $\begin{array}{l}10 \\
29\end{array}$ & $\begin{array}{l}27 \\
29\end{array}$ \\
\hline S4 & Rain style & $\begin{array}{l}\text { Dots only } \\
\text { Depicted in a style other than } \\
\text { dots }\end{array}$ & $\begin{array}{l}3 \\
34\end{array}$ & $\begin{array}{l}2 \\
42\end{array}$ & $\begin{array}{l}2 \\
37\end{array}$ & $\begin{array}{l}5 \\
51\end{array}$ \\
\hline S5 & Rain directed & $\begin{array}{l}\text { Randomly/evenly dispersed } \\
\text { Rain is directed at the person }\end{array}$ & $\begin{array}{l}36 \\
1\end{array}$ & $\begin{array}{l}42 \\
2\end{array}$ & $\begin{array}{l}38 \\
1\end{array}$ & $\begin{array}{l}52 \\
4\end{array}$ \\
\hline S6 & Rain touching & $\begin{array}{l}\text { Not touch the figure/extension } \\
\text { Touches the figure/extension }\end{array}$ & $\begin{array}{l}21 \\
16\end{array}$ & $\begin{array}{l}24 \\
20\end{array}$ & $\begin{array}{l}21 \\
18\end{array}$ & $\begin{array}{l}30 \\
26\end{array}$ \\
\hline S7 & Gets wet & $\begin{array}{l}\text { Figure is not likely to get wet } \\
\text { Figure is likely to get wet }\end{array}$ & $\begin{array}{l}21 \\
16\end{array}$ & $\begin{array}{l}34 \\
12\end{array}$ & $\begin{array}{l}26 \\
15\end{array}$ & $\begin{array}{l}37 \\
20\end{array}$ \\
\hline S8 & Wind & $\begin{array}{l}\text { No indication of wind } \\
\text { Wind indicated }\end{array}$ & $\begin{array}{l}34 \\
3\end{array}$ & $\begin{array}{l}43 \\
3\end{array}$ & $\begin{array}{l}39 \\
2\end{array}$ & $\begin{array}{l}53 \\
4\end{array}$ \\
\hline & & & \multicolumn{4}{|c|}{ Means (S.D.) $)^{1}$} \\
\hline S9 & Puddle(s) & Number of puddles & $\begin{array}{l}0.19 \\
(0.46)\end{array}$ & $\begin{array}{l}0.35 \\
(1.10)\end{array}$ & $\begin{array}{l}0.10 \\
(0.37)\end{array}$ & $\begin{array}{l}0.23 \\
(0.91)\end{array}$ \\
\hline S10 & $\begin{array}{l}\text { Standing in } \\
\text { puddle(s) }\end{array}$ & $\begin{array}{l}\text { The number of puddle that } \\
\text { the person is standing or } \\
\text { touching }\end{array}$ & $\begin{array}{l}0.08 \\
(0.28)\end{array}$ & $\begin{array}{l}0.04 \\
(0.21)\end{array}$ & 0.00 & $\begin{array}{l}0.02 \\
(0.13)\end{array}$ \\
\hline S11 & $\begin{array}{l}\text { Multiple rain } \\
\text { styles }\end{array}$ & $\begin{array}{l}0 \text { point if rain is represented as } \\
\text { only dots, } 1 \text { point per form of } \\
\text { represented rain except dots }\end{array}$ & $\begin{array}{l}0.97 \\
(0.29)\end{array}$ & $\begin{array}{l}0.96 \\
(0.30)\end{array}$ & $\begin{array}{l}0.90 \\
(0.37)\end{array}$ & $\begin{array}{l}0.98 \\
(0.40)\end{array}$ \\
\hline S12 & $\begin{array}{l}\text { Multiple } \\
\text { precipitation }\end{array}$ & $\begin{array}{l}0 \text { point if only rain is depicted, } \\
1 \text { point per type of precipitation } \\
\text { depicted in addition to rain }\end{array}$ & 0.00 & $\begin{array}{l}0.02 \\
(0.15)\end{array}$ & 0.00 & $\begin{array}{l}0.05 \\
(0.23)\end{array}$ \\
\hline S13 & $\begin{array}{l}\text { Lightning } \\
\text { bolt(s) }\end{array}$ & Number of lightning bolts & $\begin{array}{l}0.14 \\
(0.59)\end{array}$ & $\begin{array}{l}0.04 \\
(0.21)\end{array}$ & $\begin{array}{l}0.12 \\
(0.56)\end{array}$ & $\begin{array}{l}0.02 \\
(0.13)\end{array}$ \\
\hline S14 & $\begin{array}{l}\text { Lightning } \\
\text { hit(s) }\end{array}$ & $\begin{array}{l}\text { Number of lightning bolts that } \\
\text { hits the person }\end{array}$ & 0.00 & 0.00 & 0.00 & 0.00 \\
\hline S15 & Cloud(s) & Number of clouds & $\begin{array}{l}0.54 \\
(1.35)\end{array}$ & $\begin{array}{l}0.26 \\
(0.91)\end{array}$ & $\begin{array}{l}0.39 \\
(1.12)\end{array}$ & $\begin{array}{l}0.23 \\
(0.87)\end{array}$ \\
\hline S16 & $\begin{array}{l}\text { Darkened } \\
\text { cloud(s) }\end{array}$ & Number of darkened clouds & $\begin{array}{l}0.08 \\
(0.36)\end{array}$ & 0.00 & $\begin{array}{l}0.07 \\
(0.35)\end{array}$ & 0.00 \\
\hline
\end{tabular}

Note. 1-Originally calculated as frequency, it is shown as Means for simplicity of notation. 
Appendix B. The PITR Resource Index results based on military life adjustment level and resilience level.

\begin{tabular}{|c|c|c|c|c|c|c|}
\hline & \multirow[t]{3}{*}{ Item } & \multirow[t]{3}{*}{ Content } & \multicolumn{4}{|c|}{ Frequency } \\
\hline & & & \multicolumn{2}{|c|}{$\begin{array}{l}\text { Military Life } \\
\text { Adjustment }\end{array}$} & \multicolumn{2}{|l|}{ Resilience } \\
\hline & & & $\begin{array}{l}\text { Lower } \\
\text { Group } \\
(N=37)\end{array}$ & $\begin{array}{l}\text { Upper } \\
\text { Group } \\
(N=46)\end{array}$ & $\begin{array}{l}\text { Lower } \\
\text { Group } \\
(N=41)\end{array}$ & $\begin{array}{l}\text { Upper } \\
\text { Group } \\
(N=57)\end{array}$ \\
\hline R1 & Protection present & $\begin{array}{l}\text { No form of protection } \\
\text { tSome form of protection } \\
\text { indicated }\end{array}$ & $\begin{array}{l}15 \\
22\end{array}$ & $\begin{array}{l}6 \\
40\end{array}$ & $\begin{array}{l}14 \\
27\end{array}$ & $\begin{array}{l}13 \\
44\end{array}$ \\
\hline R2 & Umbrella present & $\begin{array}{l}\text { No indication of an umbrella } \\
\text { Umbrella is present }\end{array}$ & $\begin{array}{l}3 \\
19\end{array}$ & $\begin{array}{l}6 \\
34\end{array}$ & $\begin{array}{l}2 \\
25\end{array}$ & $\begin{array}{l}7 \\
37\end{array}$ \\
\hline R3 & Umbrella held & $\begin{array}{l}\text { Umbrella is dysfunctionally held } \\
\text { Person is functionally holding it }\end{array}$ & $\begin{array}{l}1 \\
18\end{array}$ & $\begin{array}{l}1 \\
33\end{array}$ & $\begin{array}{l}2 \\
23\end{array}$ & $\begin{array}{l}3 \\
34\end{array}$ \\
\hline $\mathrm{R} 4$ & $\begin{array}{l}\text { Other protective } \\
\text { device }\end{array}$ & $\begin{array}{l}\text { No other protective device } \\
\text { Other protection is included }\end{array}$ & $\begin{array}{l}20 \\
2\end{array}$ & $\begin{array}{l}36 \\
4\end{array}$ & $\begin{array}{l}25 \\
2\end{array}$ & $\begin{array}{l}39 \\
5\end{array}$ \\
\hline R5 & $\begin{array}{l}\text { Adequate size } \\
\text { ofprotection }\end{array}$ & $\begin{array}{l}\text { The same/narrower than width of } \\
\text { person } \\
\text { Larger than width of person }\end{array}$ & $\begin{array}{l}\mathrm{f} \\
3 \\
19\end{array}$ & $\begin{array}{l}6 \\
34\end{array}$ & $\begin{array}{l}4 \\
23\end{array}$ & $\begin{array}{l}11 \\
33\end{array}$ \\
\hline R6 & $\begin{array}{l}\text { Integrity of } \\
\text { protection }\end{array}$ & $\begin{array}{l}\text { Quality is compromised } \\
\text { Protection appears intact }\end{array}$ & $\begin{array}{l}0 \\
22\end{array}$ & $\begin{array}{l}0 \\
40\end{array}$ & $\begin{array}{l}1 \\
26\end{array}$ & $\begin{array}{l}0 \\
44\end{array}$ \\
\hline R7 & Raincoat & $\begin{array}{l}\text { Not wearing raincoat } \\
\text { Wearing raincoat }\end{array}$ & $\begin{array}{l}21 \\
1\end{array}$ & $\begin{array}{l}37 \\
3\end{array}$ & $\begin{array}{l}27 \\
0\end{array}$ & $\begin{array}{l}41 \\
3\end{array}$ \\
\hline $\mathrm{R} 8$ & Rain hat & $\begin{array}{l}\text { No Hat } \\
\text { There is a rain hat }\end{array}$ & $\begin{array}{l}20 \\
2\end{array}$ & $\begin{array}{l}37 \\
3\end{array}$ & $\begin{array}{l}26 \\
1\end{array}$ & $\begin{array}{l}36 \\
8\end{array}$ \\
\hline R9 & Rain boots & $\begin{array}{l}\text { Not wearing rain boots } \\
\text { Wearing protective boots }\end{array}$ & $\begin{array}{l}21 \\
1\end{array}$ & $\begin{array}{l}39 \\
1\end{array}$ & $\begin{array}{l}27 \\
0\end{array}$ & $\begin{array}{l}42 \\
2\end{array}$ \\
\hline R10 & Clothed & $\begin{array}{l}\text { Naked/Stick figure } \\
\text { Wearing any type of clothing }\end{array}$ & $\begin{array}{l}20 \\
17\end{array}$ & $\begin{array}{l}19 \\
27\end{array}$ & $\begin{array}{l}20 \\
21\end{array}$ & $\begin{array}{l}26 \\
31\end{array}$ \\
\hline R11 & Full face & $\begin{array}{l}\text { Obscured/sideways/rear view } \\
\text { Full face is in view }\end{array}$ & $\begin{array}{l}16 \\
21\end{array}$ & $\begin{array}{l}19 \\
27\end{array}$ & $\begin{array}{l}20 \\
21\end{array}$ & $\begin{array}{l}22 \\
35\end{array}$ \\
\hline R12 & Smiling & $\begin{array}{l}\text { Other than smile } \\
\text { Figure is smiling }\end{array}$ & $\begin{array}{l}27 \\
10\end{array}$ & $\begin{array}{l}33 \\
13\end{array}$ & $\begin{array}{l}33 \\
8\end{array}$ & $\begin{array}{l}44 \\
13\end{array}$ \\
\hline R13 & Centered & $\begin{array}{l}\text { Extend beyond template box } \\
\text { Within template box }\end{array}$ & $\begin{array}{l}25 \\
12\end{array}$ & $\begin{array}{l}22 \\
24\end{array}$ & $\begin{array}{l}29 \\
12\end{array}$ & $\begin{array}{l}22 \\
35\end{array}$ \\
\hline R14 & Size of figure & $\begin{array}{l}x<2 \text { inches, or } 6 \text { inches }<x \\
\text { Between } 2-6 \text { inches }\end{array}$ & $\begin{array}{l}13 \\
24\end{array}$ & $\begin{array}{l}18 \\
28\end{array}$ & $\begin{array}{l}19 \\
22\end{array}$ & $\begin{array}{l}18 \\
39\end{array}$ \\
\hline R15 & Full figure & $\begin{array}{l}\text { Partial body, side/rear view } \\
\text { Fully represented figure, facing } \\
\text { forward }\end{array}$ & $\begin{array}{l}5 \\
32\end{array}$ & $\begin{array}{l}8 \\
38\end{array}$ & $\begin{array}{l}7 \\
34\end{array}$ & $\begin{array}{l}10 \\
47\end{array}$ \\
\hline R16 & Line quality & $\begin{array}{l}\text { Line quality is varied or sketchy } \\
\text { Line quality is even and fluid }\end{array}$ & $\begin{array}{l}6 \\
31\end{array}$ & $\begin{array}{l}7 \\
39\end{array}$ & $\begin{array}{l}7 \\
34\end{array}$ & $\begin{array}{l}7 \\
50\end{array}$ \\
\hline R17 & Naked & $\begin{array}{l}\text { Figure is clothed in any way } \\
\text { Naked/unclear if clothed }\end{array}$ & $\begin{array}{l}17 \\
20\end{array}$ & $\begin{array}{l}27 \\
19\end{array}$ & $\begin{array}{l}19 \\
21\end{array}$ & $\begin{array}{l}31 \\
26\end{array}$ \\
\hline R19 & Teeth & $\begin{array}{l}\text { No teeth are visible } \\
\text { Teeth are visible represented }\end{array}$ & $\begin{array}{l}37 \\
0\end{array}$ & $\begin{array}{l}45 \\
1\end{array}$ & $\begin{array}{l}41 \\
0\end{array}$ & $\begin{array}{l}56 \\
1\end{array}$ \\
\hline & & & Means (S & D. $)^{2}$ & & \\
\hline R18 & Missing parts & $\begin{array}{l}1 \text { point per missing. (head, eyes, } \\
\text { nose, mouth, neck, torso, arms, } \\
\text { hands, fingers, legs, feet) }\end{array}$ & $\begin{array}{l}4.00 \\
(2.07)\end{array}$ & $\begin{array}{l}3.80 \\
(2.32)\end{array}$ & $\begin{array}{l}4.15 \\
(2.12)\end{array}$ & $\begin{array}{l}3.84 \\
(2.12)\end{array}$ \\
\hline
\end{tabular}

Note. 2-Originally calculated as frequency, it is shown as Means for simplicity of notation. 